Base of the

Ordovician marked

\section{in stone}

A formal ceremony to unveil a plaque marking the site of the global stratotype and point (GSSP) for the base of the Ordovician System was held at Green Point, Newfoundland, Canada on 1 June 2001. The International Commission on Stratigraphy in conjunction with Parks Canada organized the celebration to mesh with the Geological Association of Canada Annual Meeting held in St. John's, Newfoundland 28-30 May 2001. A field trip associated with that meeting brought a group interested in the stratigraphy, structure and oil potential of western Newfoundland to the region. The field trippers joined a group of former residents of Green Point, a community that was moved when Gros Morne National Park was established, and many other local people, including officials of Parks Canada.

Having visited the classic megabreccias of the Cow Head Group at Cow Head in the morning, the field trip headed to Green Point for the ceremony that was scheduled for 3:00 p.m. Godfrey Nowlan (Secretary of the International Working Group on the Cambrian-Ordovician Boundary) visited the Cow Head School in the early afternoon to make a presentation to students on the significance of the local rocks and the value of fossils in calibrating geological time. He was assisted by Rob Hingston of Parks Canada who brought some excellent specimens of local fossils for the students to look at.

The Government of Canada was represented at the Green Point ceremony by $\mathrm{Mr}$. Gerry Byrne, the Member of Parliament for Humber-St. Barbe-Baie Verte. Mr. Byrne brought greetings from the Minister of Canadian Heritage, the Honourable Sheila Copps and welcomed the assembled scientists and local residents. He noted the importance of Gros Morne National Park, in which the GSSP is located, to western Newfoundland and said: "Gros Morne has helped us to better understand and appreciate some of the many gifts of natural heritage that surround us.....and perhaps no element of that heritage takes a more prominent place than the rocks that surround us". The Government of Newfoundland and Labrador was represented by provincial paleontologist Doug Boyce who pointed out that the province now has the unique situation of having both the base and top of the Cambrian System defined in Newfoundland.

The International Working Group on the Cambrian-Ordovician Boundary, part of the Ordovician Subcommission of the International Commission on Stratigraphy, was represented by Godfrey Nowlan (Geological

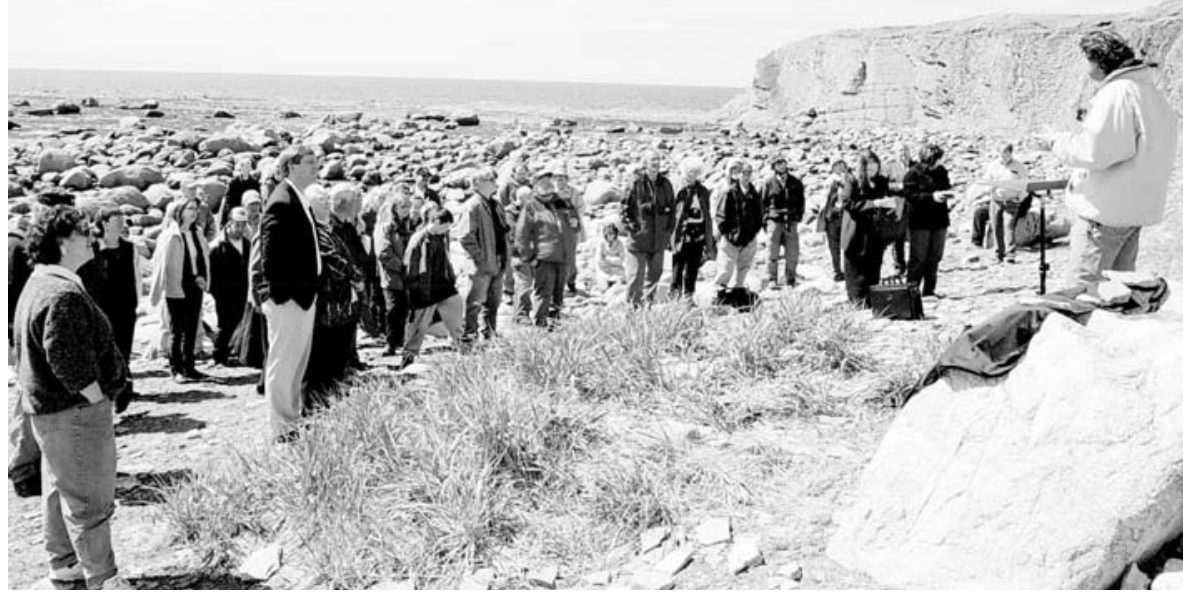

Figure 1 Stan Finney (California State University -Long Beach) addresses the participants at the unveiling of the plaque for the base of the Ordovician at Green Point.

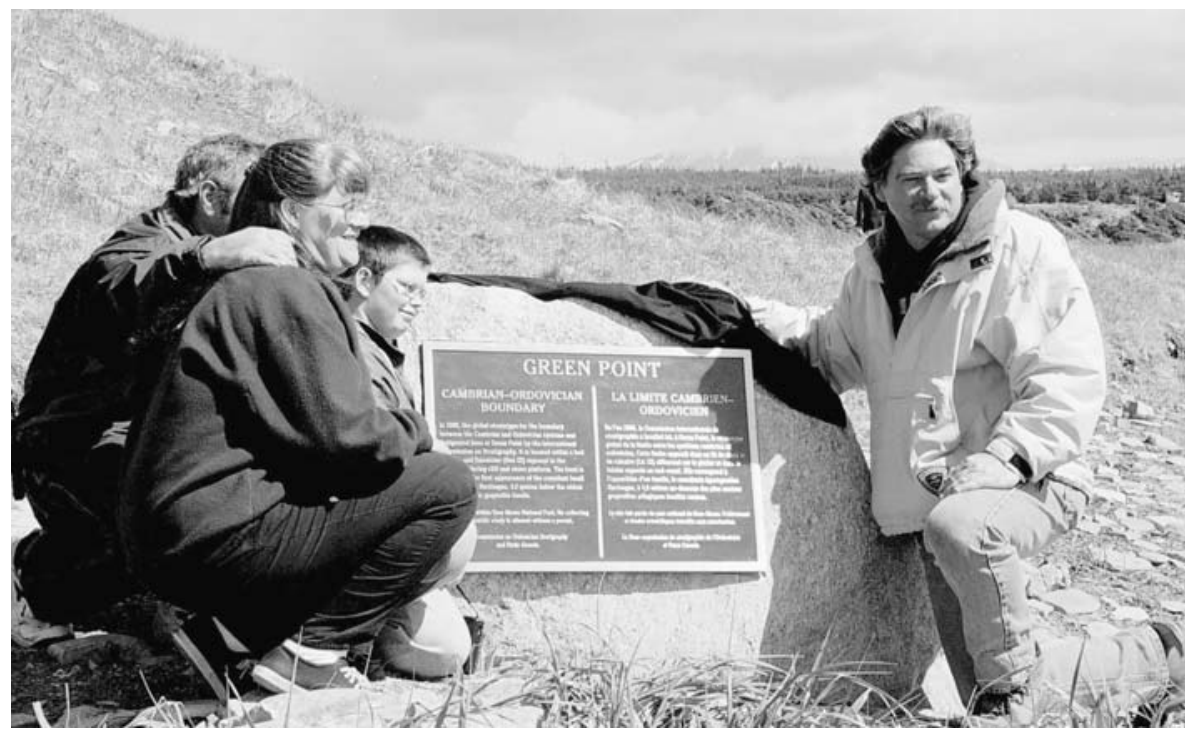

Figure 2 Rowena Gilley, daughter of Green Point's oldest settler, her husband Gerald Gilley and her son Chip Gilley share the unveiling with Stan Finney.

\section{GREEN POINT}

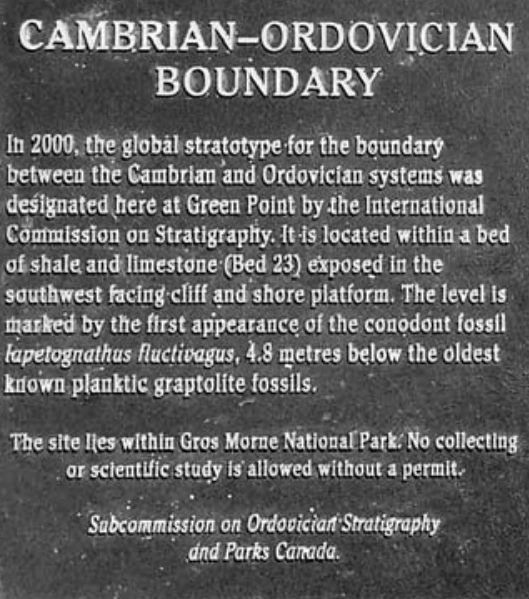

\section{BOUNDARY}

in 2000 , the global stratotype for the boundar

between the Cambriam and Ordovician systems was esignated here at Green Point by the International d within a bed ifi and shore platform. The level is harked by the first apipearance of the conodont fossil apetognathus fluctiongus, 4.8 metres below the oldest kown planktic graptolite tossil

e site lles within Gros Morne National Park: No collectin 作 and Parks Canad

\section{LA LIMITE CAMBRIEN- ORDOVICIEN}

In l'an 2000, la Commission internationale de

stratigraphile a localise icl, a Green Point, le stratotype global de la limite entre les systemes cambrien et

ordovicien. Cette limite apparaît dans un lit de shale et de calcaire (lit 23) afileurant sur le platier et dans la. falaise exposés au sud-quest. Eille correspond do

lapparition d'un fossile, le conodonte laperognathus. fluctivagus, a 4,8 metres au-desscus des plus anciens graptolites pelagiques fossiles connus.

Le site lalt partie du parc natlonal du Gros-Morne. Prelèvement et études scientifiques interdits sans autorisation. et Pars Canada.
La Sous-remmission de stratigrephie de lOrdooicien

Figure 3 The plaque describing the base of the Ordovician at Green Point, 


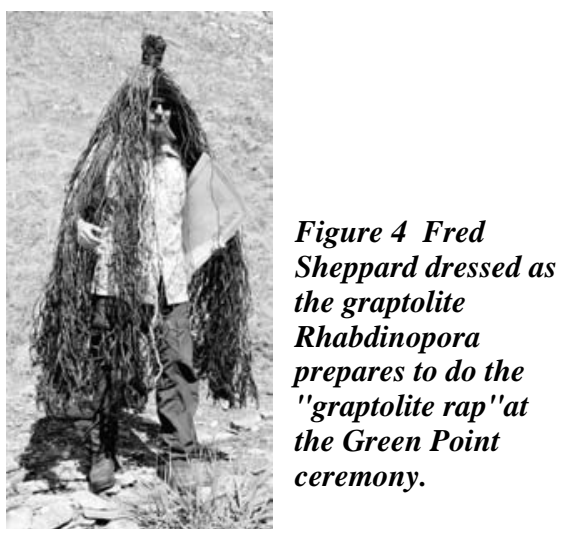

Survey of Canada) who paid tribute to the scientists who had first made the case for the Green Point section, notably Dr. Chris Barnes (University of Victoria) who was in the crowd. Dr. Nowlan went on to read comments from Roger Cooper (Institute of Geological and Nuclear Sciences in New Zealand) who chaired the Working Group but was unable to attend the ceremony. Dr. Cooper's comments included reference to modern geological science being an international collaborative venture. He noted that the ceremony marked the conclusion of 24 years of effort by scientists from around the world and indicated that he saluted their efforts. He noted that "it required a willingness to cooperate, collaborate and undertake personal research to resolve the problem of dating and correlating strata around the world at the beginning of Ordovician time". $\mathrm{He}$ also acknowledged the difficult compromise that the group had to reach in order to achieve a clear majority decision. Dr. Cooper thanked the staff of Gros Morne National Park for their cooperation and assistance with demarcation and protection of Green Point.

The final speaker at the ceremony was Dr. Stan Finney (California State University, Long Beach) who is Chairman of the Subcommission on Ordovician Stratigraphy. He highlighted the significance of world stratotypes and the process by which Green Point was selected. He acknowledged the tremendous intellectual efforts of the scientists involved in the work. Finally, he noted "Geology is a very human science and selection of this stratotype at Green Point represents the culmination of a human process, and so it is a great pleasure to dedicate this plaque today".

The plaque, bolted to a large Precambrian boulder derived from the Long Range Mountains during glaciation, was then unveiled by Mr. Byrne, Dr. Finney and former Green Point resident Mrs. Rowena Gilles, her husband Mr. Gerald Gilles and their son Chip. Mrs. Gilles is the daughter of Mrs. Martha Payne, the oldest surviving former resident of Green Point.

Rob Hingston of Parks Canada acted as emcee for the ceremony and elaborated Parks Canada's role in protecting and presenting
Park interpreter Fred Shepard who, dressed as the graptolite Rhabdinopora performed the "graptolite rap" with the enthusiastic assistance of the assembled throng.

The ceremony was followed by a reception at the Visitor Reception Centre in Rocky Harbour where foods attributed to several geological processes and extinct animals were consumed.

Godfrey Nowlan
Geological Survey of Canada,
Calgary

\section{IUGS Working Group on World Landslide Inventory and the IDNDR (1999-2000)}

\section{Introduction}

The Working Group held its last meeting in the Council Chamber of Cardiff City Hall, U.K. on June 25, 2000 immediately before the 8th International Symposium on Landslides. This note records some of the history of the Group and points out where its current activities will now continue.

The motivation of the Group (abbreviated to IUGS/WG/L) was shared with the International Decade for Natural Disaster Reduction (IDNDR).

In his call for the International Decade for Natural Disaster Reduction (1990-2000), the Secretary-General of the United Nations remarked, "A fundamental precondition for improvements in risk-assessment and disaster management capabilities is the availability of reliable historical data on disasters on a country-by-country basis" (UN, 1989).

Landslides, either alone or in association with the earthquakes, volcanic eruptions, wildfires and major rainstorms that may trigger landslides, are a major cause of loss of life, injury and property damage in natural disasters around the world. In some countries, they are the major cause of damage. So the need to establish a World Landslide Inventory is apparent. The world distribution of landslides has not yet been mapped. Landslide studies are isolated, limiting their interpretation to local factors. Analyzing the occurrence of groups of landslides will reveal the broad processes, active over a number of sites, that contribute to slope movements. There is an obvious analogy to be drawn with the study of earthquakes, now

\section{WP/WLI}

The International Geotechnical Societies' UNESCO Working Party on World Landslide Inventory (abbreviated WP/WLI) was initiated at the 5th International Symposium on Landslides (Lausanne, 1988) to assist the establishment of a detailed list of the World's landslides. The Working Party has informally defined a landslide (Cruden, 1991) as, "A movement of a mass or rock, earth or debris down a slope". Ground subsidence and snow avalanches are beyond its scope but debris flows and rock falls, for instance, interested the Party.

The Working Party was composed of the members of TC11, the Technical Committee on Landslides of the International Society for Soil Mechanics and Geotechnical Engineering, the Commission on Landslides of the International Association of Engineering Geology and the Environment (IAEG Commission 2) and nominees of National Groups of the International Society of Rock Mechanics (ISRM).

The Working Party published Suggested Methods (WP/WLI, 1990, 1991, 1993a, 1994) collected in the Multilingual Landslide Glossary (WP/WLI, 1993b).

The page within the Multilingual Glossary devoted to Landslide Types is a useful example of our work. The illustrations have been published in different versions elsewhere (Cruden et al., 1994; Cruden and Varnes, 1996; Dikau et al., 1996; ISSMFE, 1994). They show 5 numbered types of landslides. On the facing page of the Multilingual Glossary there are descriptions of the kinematic behaviour of each of the 5 types. Because the Glossary is a loose leaf document, any of the 6 languages of the Glossary (Chinese, English, French, German, Russian and Spanish) can be brought to the facing page. Texts for other languages (Arabic, Italian, Japanese, Hindi, Sinhala and Tamil for instance) have been prepared and are available from Edmund Krauter in Mainz. We are encouraging the publication of other editions of this valuable document.

\section{IUGS/WG/L}

When ISSMFE and ISRM joined the International Union of Geological Sciences (IUGS), a member of the International Council of Scientific Unions (ICSU), the Working Party could become a Working Group of IUGS with the addition of nominees from the International Association of Geomorphologists (IAG). The scientific goal of the Working Group is "assisting prediction of the occurrence and the behaviour of landslides". To this end, six specific activities were approved. Among them was "Correlation, translation and codification of various national terminologies to assist mutual understanding". The Working Group has since published a Suggested Method for describing the rate of movement of a land- 
Having provided itself with the necessary vocabulary, the Group has turned its attention to risk assessment. At its meeting in Trondheim in June, 1996, the IUGS Working Group structured its Committee on the Assessment of the Risk of Landsliding, under the Chairmanship of R. Fell. Among its objectives are:

- To review terminology and to propose internationally acceptable definitions of terms used in assessing the risk of landslides.

- To review national standards of acceptable and tolerable risk and suggest methods of applying these to landslide risk assessment.

- To review methods of predicting vulnerability of property and life to landslides.

A Workshop with invited participants was arranged by Professor Fell at the United States Geological Survey's Water Resources Center in Honolulu, Hawaii, U.S.A. through the courtesy of L. Highland, Coordinator, National Landslide Information Center, USGS, and Secretary of the IUGS Working Group. The Proceedings of the Workshop (Cruden, Fell, 1997) include theme papers on landslide risk assessment in practice (Morgenstern), systematic approaches to risk assessment and management (Einstein), landslide risk management (Fell and Hartford) and on the assessment of the consequences of landslides (Wong, Ho and Chan). 21 shorter invited papers and a summary of the final day's discussions complete coverage of the state of the art of landslide risk assessments.

With the approach of the end of the IDNDR, the Working Group arranged for its active committees to reintegrate with the Societies and Associations that had contributed to the Working Group. Technical Committee 11, Landslides of the International Society for Soil Mechanics and Geotechnical Engineering welcomed the Working Groups' Committees on Damage (Chair, H. Einstein), Rapid Landslide Movement (Chair, K. Sassa), Remediation (Chair, M. Popescu) and Risk (Chair, R. Fell). Commission 2, Landslides, of the IAEG has taken over the Committees on Geology (Chair, E. Krauter), the Multilingual Glossary (Chair, E. Krauter), the Directory of the World Landslide Inventory (Chair, L. Highland) and on Landslide Summaries (Chair, D. Cruden).

Coordination of the work of the committees will become a responsibility of the Committees and Commissions they have rejoined. Queries may be addressed to the Chair of TC 11, (Professor K. Sassa, Disaster Prevention Research Institute, Kyoto University, Japan) or the Chair of IACG Commission 2 (Professor E. Krauter, Geo International, Mainz, Germany).

\section{Acknowledgements}

It is my pleasure as Chairman to acknowledge that the achievements of the Working Groun result from the its 52 members from 33 countries. P. Anagnosti and L. Highland have been conscientious Secretaries. We have been warmly welcomed in Christchurch, Trondheim and Cardiff (Bell, 1992, Senneset, 1996, Bromhead et al., 2000). Funding for our activities has come from UNESCO, the International Union of Geological Sciences and members' travel budgets.

\section{References}

Bell, D. H., 1992, Landslides, Proceedings, 6th International Symposium, Christchurch, 10-14 February, Balkema, Rotterdam, 3 volumes, 2194p.

Bromhead, E., Dixon, N., Ibsen, M-L., 2000, Landslides in research, theory and practice. Proceedings, 8th International Symposium on Landslides, Cardiff, 26-30 June, Thomas Telford, London, 3 Volumes, 1684p.

Cruden, D.M., 1991, A simple definition of a landslide, Bulletin International Association of Engineering Geology, 43: 27-29.

Cruden, D. M., and Varnes, D. J., 1996, Landslide Types and Processes, in Turner, A.K., Schuster, R.L., eds, Landslides: Investigation and Mitigation, Transportation Research Board, Special Report 247: 36-75.

Cruden, D. M., Fell, R., editors, 1997, Landslide Risk Assessment, Balkema, Rotterdam, 371p.

Cruden, D. M., Krauter, E., Beltran, L., Lefebvre, G.,Ter-Stepanian, G., and Zhang, Z-Y., 1994. Describing landslides in several languages; The Multilingual Landslide Glossary, Proceedings, 7th International Congress, International Association of Engineering Geology, 5-9 September, Lisbon, Balkema, Rotterdam, 3: $1325-1333$.

Dikau, R., Brunsden, D., Schrott, L., and Ibsen, ML., 1996, Landslide Recognition, Wiley, Chichester, U.K., 251p.

International Union of Geological Sciences Working Group on Landslides, 1995, A suggested method for describing the rate of movement of a landslide, Bulletin International Association of Engineering Geology, 52: 75-78.

ISSMFE, 1994, Landslide Illustrations: a set of slides, International Society for Soil Mechanics and Foundation Engineering Educational Slide Sets, 16p., 26 slides.

IUGS Working Group on Landslides, 1997, Quantitative risk assessment for slopes and landslides, the state of the art, in Cruden, D. M., Fell., R., eds, Landslide Risk Assessment, Balkema, Rotterdam.

Senneset, K., 1996, Landslides, Proceedings, 7th International Symposium, Balkema, Rotterdam, 3 volumes, 1992p

UN Secretary General, 1989, International Decade for Natural Disaster Reduction, Report A/44/322, E 1989/114 Addendum 2, p.4, United Nations General Assembly, Economic and Social Council, New York.

WP/WLI (International Geotechnical Society's UNESCO Working Party on World Landslide Inventory), 1990, A suggested method for reporting a landslide, Bulletin International Association of Engineering Geology, 41: 5-12.

WP/WLI (International Geotechnical Society's UNESCO Working Party on World Landslide Inventory), 1991, A suggested method for a landslide summary, Bulletin Internatonal Association of Engineering Geology, 43: 101-110.
WP/WLI (International Geotechnical Society's UNESCO Working Party on World Landslide Inventory), 1993a, A suggested method for describing the activity of a landslide, Bulletin International Association of Engineering Geology, 47: 53-57.

WP/WLI (International Geotechnical Society's UNESCO Working Party on World Landslide Inventory), 1993b, Multilingual Landslide Glossary, Bitech, Richmond, British Columbia, 59p.

WP/WLI (International Geotechnical Society's UNESCO Working Party on World Landslide Inventory), 1994, A suggested method for describing the causes of a landslide, Bulletin International Association of Engineering Geology, 50: 71-74

\section{M. Cruden}

Department of Civil \& Envirenmental Engineering

University of Alberta

Canada, T6G 2G7 